Jurnal Inkofar * Volume 1 No. 2, Desember 2018 * ISSN: 2615-3645 (Print) / 2581-2920 (Online)

Tersedia secara online di: http://www.politeknikmeta.ac.id/meta/ojs/

\title{
PENENTUAN KARYAWAN LEMBUR DENGAN METODE ANALYTICAL HIERARCHY PROCESS (AHP)
}

\author{
Anita Sindar RMS ${ }^{1}$, Jamal Purba ${ }^{2}$ \\ ${ }^{1}$ Teknik Informatika / STMIK Pelita Nusantara / haito_ita@yahoo.com \\ ${ }^{2}$ Jamal Purba / STMIK Pelita Nusantara / jamalpurba77@gmail.com
}

\begin{abstract}
Overtime is a part of a project plan that is intended to complete a production process that is not possible to be completed in a normal working day. Overtime work must be balanced with the readiness of supporting factors including labor (employees), work materials and tools that are suitable for the needs of the job. To overcome these supporting factors, it is necessary to finance the payment of labor (wages). The problem that arises when determining employee overtime is the influence of overtime work on work productivity and the condition of employees in carrying out overtime tasks. How to determine overtime for employees will use the Analytical Hierarchy Process (AHP) method. Indicators used in determining employee overtime are the criteria for weighting. The indicator for determining overtime employees consists of three criteria, namely attitude, ability and contribution. The main output of the system, contains an alternative that has the highest weight so that the name of the employee who has to work overtime to meet the needs of the company is obtained. The advantage of the AHP method is that it makes it easy to calculate performance criteria based on priority considerations that can facilitate the determination of overtime employees.
\end{abstract}

Keywords : Overtime Work, Criteria, Sub-Criteria, Weight, AHP Method

\begin{abstract}
ABSTRAK
Kerja lembur merupakan bagian rencana proyek yang dimaksudkan untuk menyelesaikan proses produksi yang tidak mungkin diselesaikan dalam hari kerja biasa/normal shift. Pekerjaan lembur harus diimbangi dengan kesiapan faktor-faktor penunjang antara lain tenaga kerja (karyawan), material dan alat kerja yang sesuai dengan kebutuhan pekerjaan tersebut. Untuk mengatasi faktor-faktor penunjang ini diperlukan pembiayaan pembayaran tenaga kerja (upah). Permasalahan yang muncul ketika menentukan lembur karyawan adalah pengaruh kerja lembur terhadap produktivitas kerja serta kondisi karyawan dalam melaksanakan tugas lembur. Cara menentukan lembur bagi karyawan akan menggunakan Metode AHP (Analytical Hierarchy Process). Indikator yang dipergunakan dalam penentuan lembur karyawan menjadi kriteria dalam pembobotan. Indikator penentuan karyawan lembur terdiri dari tiga kriteria yaitu sikap, kemampuan dan kontribusi. Output utama dari sistem, memuat alternatif yang memiliki bobot paling tinggi sehingga diperoleh nama karyawan yang harus lembur untuk memenuhi kebutuhan perusahaan. Keunggulan Metode AHP adalah mempermudah menghitung kriteria kinerja berdasarkan pertimbangan prioritas yang dapat mempermudah dalam penentuan karyawan lembur.
\end{abstract}

Kata Kunci : Lembur, Kriteria, Subkriteria, Bobot, Metode AHP

\section{PENDAHULUAN}

Proses produksi dalam lingkungan industri/perusahaan saat ini umumnya membutuhkan waktu pelaksanaan yang cepat. Waktu pelaksanaan yang cepat ini antara lain mempunyai tujuan untuk mengejar target produksi sesuai dengan kontrak kerja atau karena suatu alasan 
Jurnal Inkofar * Volume 1 No. 2, Desember 2018 * ISSN: 2615-3645 (Print) / 2581-2920 (Online)

Tersedia secara online di: http://www.politeknikmeta.ac.id/meta/ojs/

tertentu. Untuk mengembangkan hal ini dilakukan sistem kerja lembur [1]. Pada hakekatnya kerja lembur adalah suatu hak bagi pekerja atau buruh. Makna dari hak tersebut adalah pekerja dapat memutuskan dan memilih apakah akan melakukan kerja lembur seperti yang dimintakan oleh perusahaan.

Sistem pendukung keputusan ditujukan untuk keputusan-keputusan yang memerlukan penilaian atau keputusan-keputusan yang sama sekali tidak didukung oleh algoritma. sistem pendukung keputusan adalah suatu sistem berbasis komputer yang dapat menghasilkan alternatif terbaik yang telah ditentukan berdasarkan kriteria-kriteria tertentu unuk membantu para pengambil keputusan dalam menentukan keputusan secara objektif [2]. Metode Analytic Hierarchy Process (AHP) merupakan teori umum mengenai pengukuran. Metode AHP merupakan sitem pendukung keputusan menggunakan perhitungan matrik berpasangan. Penggunaan AHP dimulai dengan membuat struktur hirarki atau jaringan dari permasalahan yang ingin diteliti. Di dalam hirarki terdapat tujuan utama, kriteria-kriteria, sub kriteria-sub kriteria dan alternatif-alternatif yang akan dibahas [3]. Memiliki hirarki yang komplek antara lain tujuan, kriteria, subkriteria perhitungannya sampai level yang paling bawah dari subkriteria tersebut. Empat skala pengukuran yang biasanya digunakan secara berurutan yaitu skala nominal, ordinal, interval dan rasio. Skala yang lebih tinggi dapat dikategorikan menjadi skala yang lebih rendah, namun tidak sebaliknya [4]. Metode AHP mempunyai kemampuan untuk memecahkan masalah yang multi-obyektif dan multi-kriteria yang berdasar pada perbandingan preferensi dari setiap elemen dalam hirarki.

Prinsip kerja AHP merupakan penyederhanaan suatu persolan kompleks yang tidak terstruktur, stratejik dan dinamik menjadi bagian-bagiannya, serta menata dalam suatu hierarki. Beberapa kriteria penilaian yang umum digunakan dalam memutuskan karyawan lembur, dalam permasalahan ini sikap, kemampuan dan kontribusi menjadi nilai penting. Sikap karyawan sehari-hari terhadap pekerjaan yang dihadapi menunjukkan loyalitas yang dapat dilihat dari gairah atau ketertarikan dalam melakukan pekerjaan. Apabila seseorang tertarik pada pekerjaan tersebut maka akan timbul tanggungjawab terhadap pekerjaan. Kemampuan karyawan dalam menyelesaikan tugas-tugas sesuai job description akan membantu hasil produksi perusahaan. Kontribusi karyawan dalam mengembangkan perusahaan dapat dinilai dari kesiapan karyawan melakukan tugas-tugas lain yang menunjang pencapaian perusahaan [5].

Konsep dasar AHP adalah penggunaan matriks pairwise comparison (matriks perbandingan berpasangan) untuk menghasilkan bobot relatif antar kriteria maupun alternatif. Dalam artikel berjudul Sistem Pendukung Keputusan Menggunakan Metode Analytic Hierarchy Process (AHP) Pemilihan Metode Pembelajaran untuk Mata Kuliah Praktikum yang Berbasiskan Bahasa Pemrograman Komputer, dijelaskan Alternatif yang memiliki bobot tertinggi digunakan sebagai bahan pendukung pengambilan keputusan bagi Dosen pengampu mata kuliah praktikum berbasiskan bahasa pemrograman komputer untuk diaplikasikan.

\section{METODE PENELITIAN}

\subsection{Metode Analytic Hierarchy Process (AHP)}

Terdapat 4 aksioma-aksioma yang terkandung dalam model AHP (Saaty, 2001) [6] :

1. Reciprocal Comparison artinya pengambilan keputusan harus dapat memuat perbandingan dan menyatakan preferensi.

2. Homogenity artinya preferensi seseorang harus dapat dinyatakan dalam skala terbatas atau dengan kata lain elemen-elemennya dapat dibandingkan satu sama lainnya.

3. Independence artinya preferensi dinyatakan dengan mengasumsikan bahwa kriteria tidak dipengaruhi oleh alternatif-alternatif yang ada melainkan oleh objektif keseluruhan.

4. Expectation artinya untuk tujuan pengambil keputusan. Struktur hirarki diasumsikan lengkap. 
Jurnal Inkofar * Volume 1 No. 2, Desember 2018 * ISSN: 2615-3645 (Print) / 2581-2920 (Online)

Tersedia secara online di: http://www.politeknikmeta.ac.id/meta/ojs/

Tahapan pengolahan data dimulai dengan menyusun hirarki berdasarkan data kriteria penentuan karyawan lembur yang telah ditetapkan (Gambar 1).

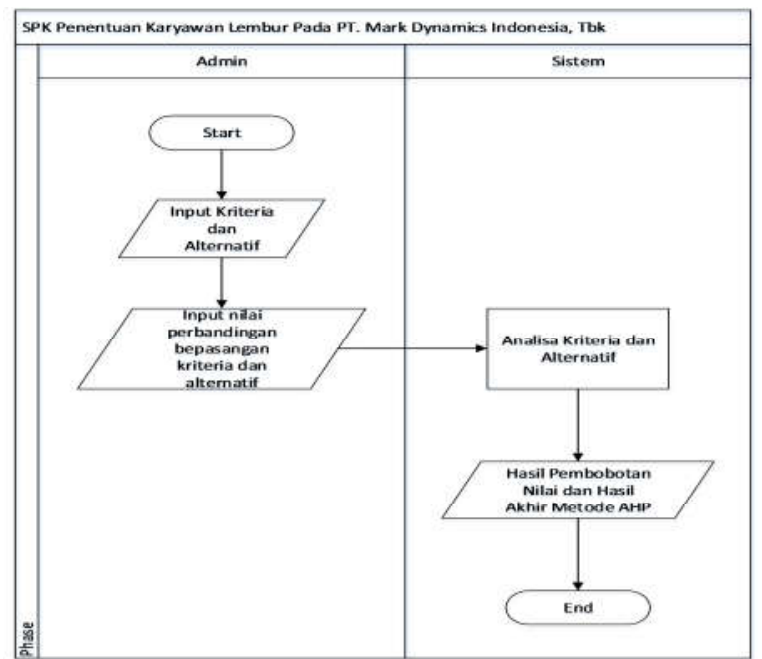

\section{Gambar 1. Flowchart Penetuan Karyawan Lembur}

Susunan hirarki dimulai dengan goal atau sasaran, lalu kriteria level pertama dan dilanjutkan dengan subkriteria.

Prinsip Metode AHP [6]:

1. Membuat hirarki

Sistem yang kompleks bisa diatasi denganmemecahnya menjadi elemen-elemen pendukung, menyusun elemen secara hierarki dan menggabungkannya atau mensistensinya [7].

2. Penilaian kriteria dan alternatif

Kriteria dan alternatif dilakukan dengan perbandingan berpasangan, untuk berbagai, skala 1 sampai 9 adalah skala terbaik untuk mengerkspresikan pendapat.

3. Synthesis of priority (menentukan prioritas)

Untuk setiap kriteria dan alternatif, perlu dilakukan perbandingan berpasangan (pairwise comparisons). Nilai-nilai perbandingan relatif dan selutuh alternatif kriteria bisa disesuaikan dengan judgement yang telah ditentukan untuk menghasilkan bobot dan prioritas. Bobot dan prioritas dihitung dengan memanipulasi matiks atau melalui penyelesaian persamaan matematika.

4. Logical consistency (konsistensi logis)

Konsistensi memiliki dua makna, pertama, objek-objek yang serupa bisa dikelompokkan sesuai dengan keseragaman dan relevansi. Kedua, menyangkut tingkat hubungan antar objek yang didasarkan pada kriteria tertentu.

Langkah-langkah metode AHP meliputi [8], [9]:

1. Mendefinisikan masalah dan menentukan solusi yang diinginkan, lalu menyusun hirarki dari permasalahan yang dihadapi.

2. Menentukan prioritas elemen. Matriks perbandingan berpasangan diisi menggunakan bilangan untuk merepresentasikan kepentingan relatif dari suatu elemen terhadap elemen lainnya.

3. Sintesis. Pertimbangan-pertimbangan terhadap perbandingan berpasangan disentesis untuk memperoleh keseluruhan prioritas.

Hal-hal yang dilakukan dalam langkah ini adalah :

1. Menjumlahkan nilai-nilai dari setiap kolom pada matriks.

Membagi setiap nilai dari kolom dengan total kolom yang bersangkutan untuk memperoleh normalisasi matriks. 
Jurnal Inkofar * Volume 1 No. 2, Desember 2018 * ISSN: 2615-3645 (Print) / 2581-2920 (Online)

Tersedia secara online di: http://www.politeknikmeta.ac.id/meta/ojs/

2. Menjumlahkan nilai-nilai dari setiap baris dan membaginya dengan jumlah elemen untuk mendapatkan nilai rata-rata.

3. Mengukur konsistensi

Dalam pembuatan keputusan, penting untuk mengetahui seberapa baik konsistensi yang ada karena pengguna tidak menginginkan keputusan berdasarkan pertimbangan dengan konsistensi yang rendah.

4. Kalikan setiap nilai pada kolom pertama dengan prioritas relative elemen pertama, nilai pada kolom kedua dengan prioritas relatif elemen kedua, dan seterusnya.

5. Jumlahkan setiap baris.

Hasil dari penjumlahan baris dibagi dengan elemen prioritas relative yang bersangkutan.

6. Jumlahkan hasil bagi di atas dengan banyaknya elemen yang ada, hasilnya disebut $\lambda$ maks.

7. Hitung Consistency Index (CI)

$$
\mathrm{CI}=(\lambda \text { maks- } \mathrm{n}) \mathrm{n} ; \mathrm{n}=\text { banyaknya elemen. }
$$

8. Hitung Rasio Konsistensi atau Consistency Ratio (CR) dengan rumus :

$$
\begin{aligned}
& \mathrm{CR}=\mathrm{CI} / \mathrm{IR} \\
& \mathrm{CR}=\text { Consistency Ratio } \\
& \mathrm{CI}=\text { Consistency Index } \\
& \mathrm{IR}=\text { Index Random Consistency }
\end{aligned}
$$

9. Memeriksa konsistensi hierarki. Jika nilainya lebih dari $10 \%$ maka penilaian data judgement harus diperbaiki. Namun jika rasio konsistensi (CI/IR) kurang atau sama dengan 0,1 maka hasil perhitungan bisa dinyatakan benar.

\subsection{Rancangan Sistem}

Rancangan antar muka merupakan gambaran struktur hirarki dan keseluruhan tampilan sistem. Rancangan sistem penetuan lembur karyawan :

\section{a. Use case}

Sasaran permodelan use case adalah untuk mendefinisikan kebutuhan fungsional dan operasional.

b. Activity Diagram

Activity diagram menggambarkan proses-proses yang terjadi dari aktivitas dimulai sampai aktivitas berhenti.

c. Class Diagram

Class diagram menampilkan kelas-kelas yang berada dalam sistem, yang memiliki hubungan dan ketergantungan. Class diagram menampilkan boundary, control dan entity (Gambar 2).



Gambar 2. Class Diagram Rancangan Sistem 
Jurnal Inkofar * Volume 1 No. 2, Desember 2018 * ISSN: 2615-3645 (Print) / 2581-2920 (Online)

Tersedia secara online di: http://www.politeknikmeta.ac.id/meta/ojs/

\section{HASIL DAN PEMBAHASAN}

Indikator penentuan karyawan lembur yaitu :

1. Kemampuan yang terdiri dari keterampilan, pengetahuan kerja, pemahaman.

2. Sikap terdiri dari inisiatif, tanggung jawab, disiplin, kehadiran, rajin.

3. Konstribusi terdiri dari kualitas pekerjaan dan jumlah pekerjaan.

Hirarki untuk menentukan karyawan lembur pada PT. Mark Dynamics Indonesia, Tbk adalah sebagai berikut (Gambar 3) :

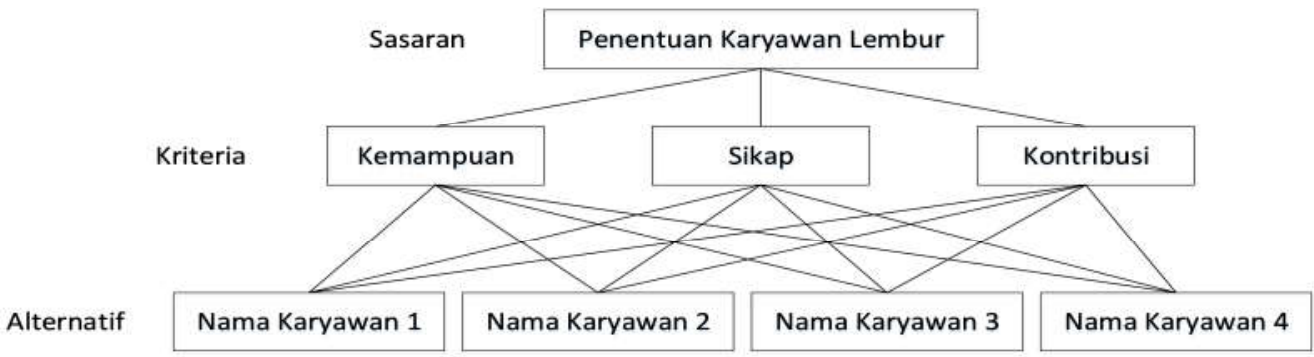

Gambar 3. Hirarki Kriteria Karyawan

Tahapan perhitungan Metode AHP dalam menentukan karyawan lembur :

1. Menentukan matrix perbandingan berpasangan kriteria

2. Hitung bobot kriteria.

3. Hitung CI.

4. Perhitungan bobot alternatif untuk kriteria sikap.

5. Perhitungan bobot alternatif untuk kriteria kemampuan

6. Perhitungan bobot alternatif untuk kriteria kontribusi.

7. Perangkingan alternatif (hasil penjumlahan dari perkalian setiap bobot alternatif dengan bobot kriteria yang bersesuaian

Tahap perhitungan AHP :

1. Hitung bobot kriteria

a. Menjadikan nilai perbandingan berpasangan menjadi nilai desimal dan menjumlahkan setiap kolomnya.

Tabel 1. Mengubah Nilai Perbandingan menjadi Nilai Desimal

\begin{tabular}{l|c|c|c|} 
& Sikap & Kemampuan & Konstribusi \\
\hline Sikap & 1,00 & 3,00 & 5,00 \\
Kemampuan & 0,33 & 1,00 & 3,00 \\
Konstribusi & 0,20 & 0,33 & 1,00 \\
Jumlah & 1,53 & 4,33 & 9,00
\end{tabular}

Kolom $1: 1,00+0,33+0,20=1,53$. Begitu seterusnya sampai nilai terpenuhi

b. Normalisasi nilai setiap kolom matrik berpandingan berpasangan dengan membagi setiap nilai pada kolom matrik dengan hasil penjumlahan kolom yang bersesuaian.

\begin{tabular}{l|c|c|c}
\multicolumn{4}{c}{ Tabel 2. Normalisasi Kriteria } \\
& Sikap & Kemampuan & Kontribusi \\
\hline Sikap & 0,6522 & 0,6923 & 0,5556 \\
Kemampuan & 0,2174 & 0,2308 & 0,3333 \\
Kontribusi & 0,1304 & 0,0769 & 0,1111
\end{tabular}


Cara normalisasi setiap nilai : Nilai kolom 1 baris 1 (1) dibagi dengan hasil penjumlahan perkolom $(1,53)$ hasilnya masuk kolom 1 baris $1(0,6222)$. Begitu seterusnya sampai semua nilai terpenuhi.

c. Hitung nilai rata-rata dari penjumlahan setiap baris matrik

Tabel 3. Nilai Priority Vektor Kriteria

\begin{tabular}{l|c|c|c|c} 
& Sikap & Kemampuan & Kontribusi & Priority Vektor \\
\hline Sikap & 0,6522 & 0,6923 & 0,5556 & 0,6333 \\
Kemampuan & 0,2174 & 0,2308 & 0,3333 & 0,2605 \\
Kontribusi & 0,1304 & 0,0769 & 0,1111 & 0,1062
\end{tabular}

Mendapatkan nilai priority vektor :

Baris $1:(0,6522+0,6923+0,5556) / \mathrm{n}=0,6333$

Baris $2:(0,2174+0,2308+0,3333) / \mathrm{n}=0,2605$

Baris $3:(0,1304+0,0769+0,1111) / \mathrm{n}=0,1062$

$\mathrm{n}=$ jumlah kriteria yang dipakai

2. Hitung CI

\begin{tabular}{l|c|c|c|c}
\multicolumn{5}{|c}{ Tabel 4 Menghitung CI } \\
& Sikap & Kemampuan & Kontribusi & Priority Vektor \\
\hline Sikap & 1 & 3 & 5 & 0,6333 \\
Kemampuan & 0,33 & 1 & 3 & 0,2605 \\
Kontribusi & 0,2 & 0,33 & 1 & 0,1062 \\
Jumlah & 1,53 & 4,33 & 9 &
\end{tabular}

$\lambda \max =(1,53 \times 0,6333)+(4,33 \times 0,2605)+(9 \times 0,1062)=3,06$

$\mathrm{CI}=(\lambda \max -\mathrm{n}) /(\mathrm{n}-1)$

$=(3,06-3) /(3-1)=0,03$

\begin{tabular}{c|c|c|c|c|c|c|c|c|c|c} 
Tabel 5. Index Ratio \\
$\mathbf{N}$ & 1 & 2 & 3 & 4 & 5 & 6 & 7 & 8 & 9 & 10 \\
\hline $\mathbf{R I}$ & 0 & 0 & 0,58 & 0,9 & 1,12 & 1,24 & 1,32 & 1,41 & 1,45 & 1,49
\end{tabular}

Untuk $\mathrm{n}=3, \mathrm{IR}=0,58$

Sehingga :

$\mathrm{CR}=\mathrm{CI} / \mathrm{IR}=0,03 / 0,58=0,025$ (konsisten)

Jika hasil perhitungan CR lebih kecil atau sama dengan 0,1 , maka kriteria dinyatakan konsisten.

3. Perhitungan bobot alternatif untuk kriteria sikap

a. Berpandingan berpasangan

Tabel 6. Berpandingan Berpasangan Kriteria Sikap

\begin{tabular}{l|c|c|c|c} 
& Angga & Arnol & Iqbal & Dwiko \\
\hline Angga & 1 & 2 & 1 & 5 \\
Arnol & 1 & 1 & 2 & 5 \\
Iqbal & $1 / 2$ & $1 / 2$ & 1 & 2 \\
Dwiko & $1 / 5$ & $1 / 5$ & $1 / 2$ & 1
\end{tabular}


Jurnal Inkofar * Volume 1 No. 2, Desember 2018 * ISSN: 2615-3645 (Print) / 2581-2920 (Online)

Tersedia secara online di: http://www.politeknikmeta.ac.id/meta/ojs/

b. Bobot kriteria (priority vektor)

Tabel 7. Desimal dan Jumlah Tiap Kolom

\begin{tabular}{l|l|l|l|l} 
& Angga & Arnol & Iqbal & Dwiko \\
\hline Angga & 1,00 & 1,00 & 2,00 & 5,00 \\
Arnol & 1,00 & 1,00 & 2,00 & 5,00 \\
Iqbal & 0,50 & 0,50 & 1,00 & 2,00 \\
Dwiko & 0,20 & 0,20 & 0,50 & 1,00 \\
Jumlah & 2,70 & 2,70 & 5,50 & 13,00
\end{tabular}

Tabel 8. Normalisasi

\begin{tabular}{l|l|l|l|l} 
& Angga & Arnol & Iqbal & Dwiko \\
\hline & & & & \\
Angga & 0,3704 & 0,3704 & 0,3636 & 0,3846 \\
Arnol & 0,3704 & 0,3704 & 0,3636 & 0,3846 \\
Iqbal & 0,1852 & 0,1852 & 0,1818 & 0,1538 \\
Dwiko & 0,0741 & 0,0741 & 0,0909 & 0,0769
\end{tabular}

Tabel 9. Mendapatkan Nilai Priority

\begin{tabular}{l|l|l|l|l|l} 
& Angga & Arnol & Iqbal & Dwiko & Bobot \\
\hline Angga & 0,3704 & 0,3704 & 0,3636 & 0,3846 & 0,3722 \\
Arnol & 0,3704 & 0,3704 & 0,3636 & 0,3846 & 0,3722 \\
Iqbal & 0,1852 & 0,1852 & 0,1818 & 0,1538 & 0,1765 \\
Dwiko & 0,0741 & 0,0741 & 0,0909 & 0,0769 & 0,0790
\end{tabular}

4. Perhitungan bobot alternatif untuk kriteria kemampuan untuk

a. Berpandingan berpasangan

Tabel 10. Berpandingan Berpasangan Kriteria Kemampuan

\begin{tabular}{l|l|l|l|l} 
& Angga & Arnol & Iqbal & Dwiko \\
\hline Angga & 1 & 3 & 2 & 5 \\
Arnol & $1 / 3$ & 1 & 4 & 2 \\
Iqbal & $1 / 2$ & $1 / 4$ & 1 & 2 \\
Dwiko & $1 / 5$ & $1 / 5$ & $1 / 2$ & 1
\end{tabular}

b. Bobot kriteria (priority vector)

Tabel 11. Mendesimalkan dan Menjumlahkan Tiap Kolom

\begin{tabular}{l|l|l|l|l} 
& Angga & Arnol & Iqbal & Dwiko \\
\hline Angga & 1,00 & 3,00 & 2,00 & 5,00 \\
Arnol & 0,33 & 1,00 & 4,00 & 5,00 \\
Iqbal & 0,50 & 0,25 & 1,00 & 2,00 \\
Dwiko & 0,20 & 0,20 & 0,50 & 1,00 \\
Jumlah & 2,03 & 4,45 & 7,50 & 13,00
\end{tabular}

Tabel 12. Normalisasi

\begin{tabular}{l|l|l|l|l} 
& Angga & Arnol & Iqbal & Dwiko \\
\hline Angga & 0,4918 & 0,6742 & 0,2667 & 0,3846 \\
Arnol & 0,1639 & 0,2247 & 0,5333 & 0,3846 \\
Iqbal & 0,2459 & 0,0562 & 0,1333 & 0,1538 \\
Dwiko & 0,0984 & 0,0449 & 0,0667 & 0,0769
\end{tabular}


Jurnal Inkofar * Volume 1 No. 2, Desember 2018 * ISSN: 2615-3645 (Print) / 2581-2920 (Online)

Tersedia secara online di: http://www.politeknikmeta.ac.id/meta/ojs/

\begin{tabular}{l|l|l|l|l|l}
\multicolumn{7}{c}{ Tabel 13. Nilai Priority } \\
& Angga & Arnol & Iqbal & Dwiko & Bobot \\
\hline Angga & 0,4918 & 0,6742 & 0,2667 & 0,3846 & 0,4543 \\
Arnol & 0,1639 & 0,2247 & 0,5333 & 0,3846 & 0,3267 \\
Iqbal & 0,2459 & 0,0562 & 0,1333 & 0,1538 & 0,1473 \\
Dwiko & 0,0984 & 0,0449 & 0,0667 & 0,0769 & 0,0717
\end{tabular}

5. Perhitungan bobot alternatif untuk kriteria kontribusi

Tabel 14. Perbandingan Berpasangan

\begin{tabular}{l|c|c|c|c} 
& Angga & Arnol & Iqbal & Dwiko \\
\hline Angga & 1 & 2 & 2 & 5 \\
Arnol & $1 / 2$ & 1 & 3 & 4 \\
Iqbal & $1 / 2$ & $1 / 3$ & 1 & 2 \\
Dwiko & $1 / 5$ & $1 / 4$ & $1 / 2$ & 1
\end{tabular}

6. Bobot kriteria (priority vector)

Tabel 15. Mendesimalkan Dan Menjumlahkan Tiap Kolom

\begin{tabular}{l|l|l|l|l} 
& Angga & Arnol & Iqbal & Dwiko \\
\hline Angga & 1,00 & 2,00 & 2,00 & 5,00 \\
Arnol & 0,50 & 1,00 & 3,00 & 4,00 \\
Iqbal & 0,50 & 0,33 & 1,00 & 2,00 \\
Dwiko & 0,20 & 0,25 & 0,50 & 1,00 \\
Jumlah & 2,20 & 3,58 & 6,50 & 12,00
\end{tabular}

Tabel 16. Normalisasi

\begin{tabular}{l|l|l|l|l} 
& Angga & Arnol & Iqbal & Dwiko \\
\hline Angga & 0,4545 & 0,5581 & 0,3077 & 0,4167 \\
Arnol & 0,2273 & 0,2791 & 0,4615 & 0,3333 \\
Iqbal & 0,2273 & 0,0930 & 0,1538 & 0,1667 \\
Dwiko & 0,0909 & 0,0698 & 0,0769 & 0,0833
\end{tabular}

Tabel 17. Mendapatkan Nilai Priority

\begin{tabular}{l|l|l|l|l|l} 
& Angga & Arnol & Iqbal & Dwiko & Bobot \\
\hline Angga & 0,4545 & 0,5581 & 0,3077 & 0,4167 & 0,4343 \\
Arnol & 0,2273 & 0,2791 & 0,4615 & 0,3333 & 0,3253 \\
Iqbal & 0,2273 & 0,0930 & 0,1538 & 0,1667 & 0,1602 \\
Dwiko & 0,0909 & 0,0698 & 0,0769 & 0,0833 & 0,0802
\end{tabular}

7. Perangkingan Alternatif

Hasil penjumlahan dari perkalian setiap bobot alternatif dengan bobot kriteria yang bersesuaian.

\begin{tabular}{l|l|l|l|l|l}
\multicolumn{7}{c}{ Tabel 18. Perangkingan } \\
& & Angga & Arnol & Iqbal & Dwiko \\
\hline Sikap & $\mathbf{0 , 6 3 3 3}$ & 0,3722 & 0,3722 & 0,1765 & 0,0790 \\
Kemampuan & $\mathbf{0 , 2 6 0 5}$ & 0,4543 & 0,3267 & 0,1473 & 0,0717 \\
Kontribusi & $\mathbf{0 , 1 0 6 2}$ & 0,4343 & 0,3253 & 0,1602 & 0,0802 \\
Priority Vektor & & 0,4470 & 0,3262 & 0,1520 & 0,0748
\end{tabular}


Dari tabel di atas, dapat disimpulkan bahwa yang memiliki skor paling tinggi adalah Angga dengan nilai 0,4470 $(0,45)$ dan Arnol dengan nilai 0,3262 $(0,33)$ maka yang akan melakukan kerja lembur untuk memenuhi kebutuhan produksi perusahaan adalah Angga dan Arnol.

Sesuai studi kasus, perhitungan AHP diimplemetasikan pada sistem. Hasil rancangan sistem terdiri dari beberapa form yang menunjukkan penginputan data, proses dan hasil perhitungan. Data kriteria penentuan lembur karyawan. Kode Kriteria : $\mathrm{C} 1=$ Sikap, $\mathrm{C} 2=$ Kemampuan, C3 = Kontribusi (Gambar 4).

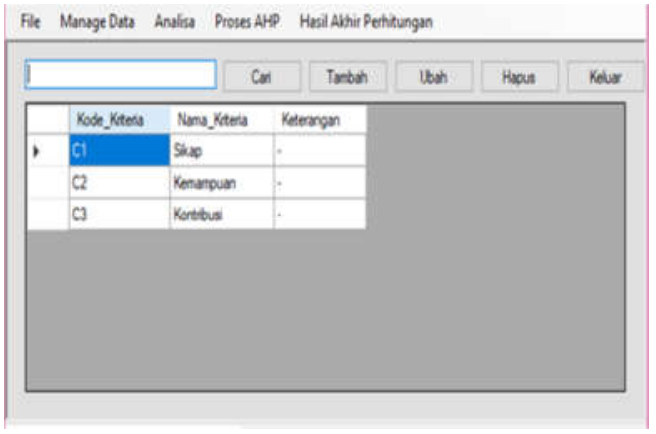

Gambar 4. Form Data Kriteria

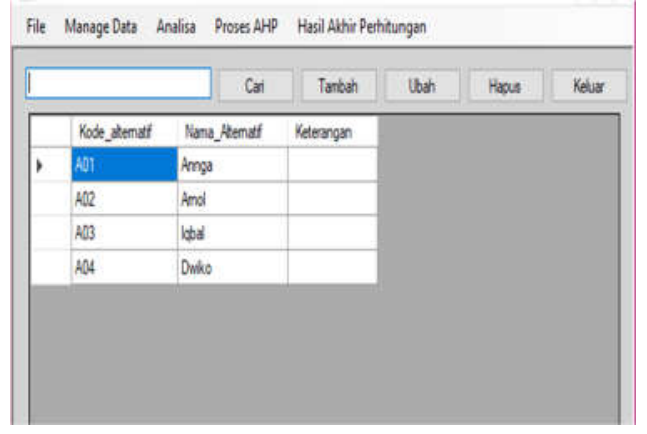

Gambar 5. Form Data Alternatif

Setiap data karyawan diberi Kode Alternatif A01, A02, A03, dan Nama Alternatif Angga, Arnol, Iqbal, Dwiko (Gambar 5).

Form perbandingan berpasangan kriteria (Gambar 6) digunakan untuk memasukkan nilainilai perbandingan antar kriteria dari data kriteria yang sudah dimasukkan. From ini juga berfungsi untuk memproses data kriteria dan juga nilai baris beserta kolom sehingga mendapatkan bobot prioritas.

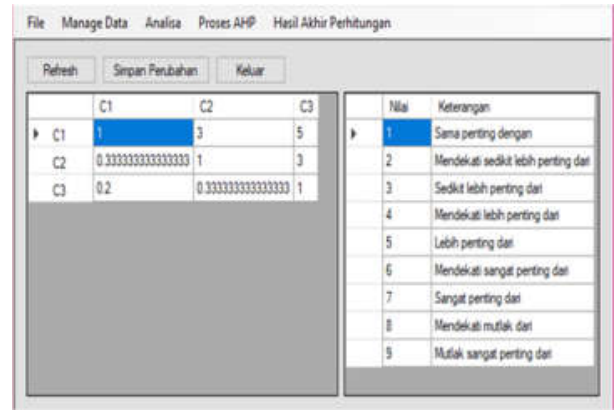

Gambar 6. Form Perbandingan
Berpasangan

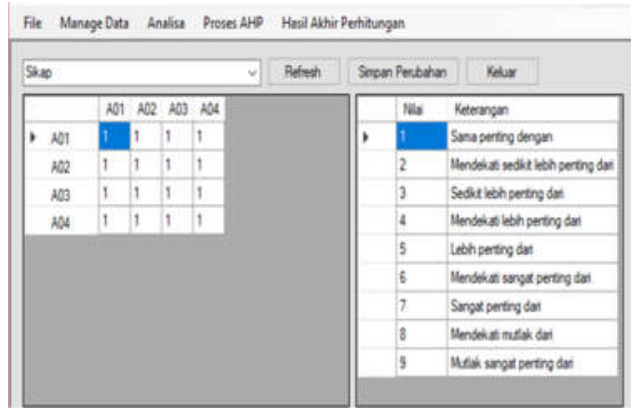

Gambar 7. Matrik Bobot Kriteria

Form perbandingan berpasangan alternatif digunakan untuk memasukkan nilai-nilai perbandingan antar alternatif dari data alternatif yang sudah dimasukkan. From ini juga berfungsi untuk memproses data alternatif dan juga nilai baris beserta kolom sehingga mendapatkan bobot prioritas. Form proses ini merupakan tampilan untuk hasil perhitungan dari nilai perbandingan untuk kriteria dan alternatif yang sudah dimasukkan dari analisa kriteria dan alternatif. Form ini menampilkan hasil perbandingan nilai antar kriteria dan alternatif yang telah dimasukkan. Setelah nilai perbandingan dimasukkan maka sistem akan menghitung jumlah tiap kolom dan akan ditampilkan dalam form ini. Untuk pengujian dari form ini adalah hasil yang ditempilkan sesuai dengan nilai perbandingan yang diimputkan dan pernjumlahannya sudah tepat. Pada form Matrik Bobot Kriteria (Gambar 7) ditampilkan 
Jurnal Inkofar * Volume 1 No. 2, Desember 2018 * ISSN: 2615-3645 (Print) / 2581-2920 (Online)

Tersedia secara online di: http://www.politeknikmeta.ac.id/meta/ojs/

bobot krtieria dimana bobot kriteria dihasilkan dari perkalian tiap-tiap kolom dan baris dengan jumlah masing-masing kolom. Nilai untuk CI, IR, dan CR juga sudah ditampilkan di form tersebut. Untuk nilai $\mathrm{CR}$, jika nilainya dibawan 0,1 maka hasilnya akan konsisten (Gambar 8)
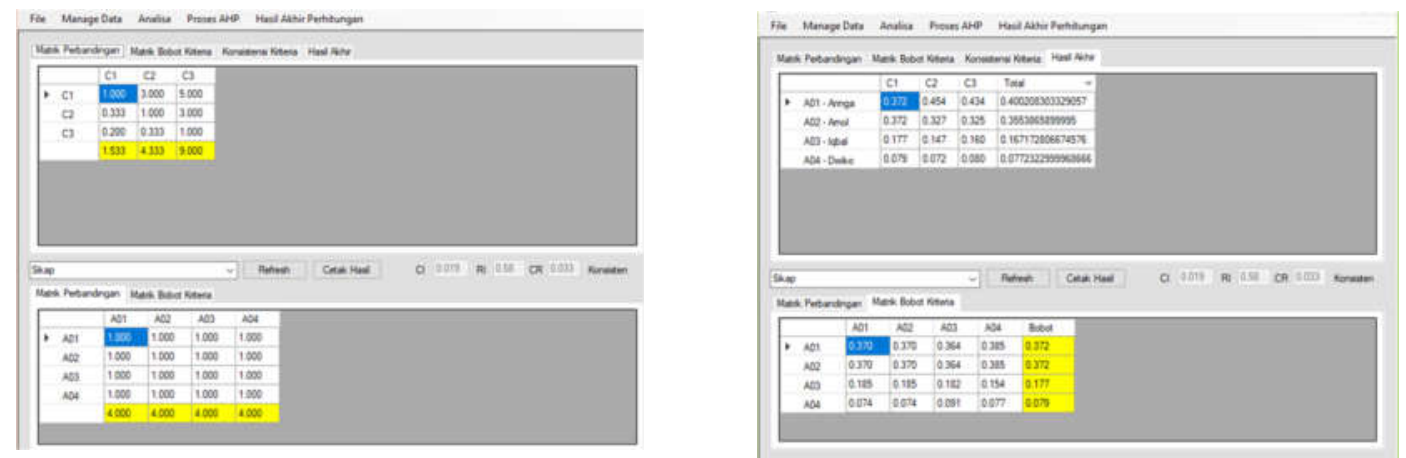

\section{Gambar 8. Form Perhitungan dan Hasil Metode AHP}

Output utama dari sistem, memuat alternatif mana yang memiliki bobot paling tinggi sehingga diperoleh nama karyawan yang harus lembur untuk memenuhi kebutuhan perusahaan. Dari hasil menunjukkan bahwa Angga memiliki skor paling tinggi sehingga Angga diharuskan lembur untuk memenuhi kebutuhan produksi perusahaan. Form ini merupakan hasil akhir dari perhitungan AHP (Gambar 8).

\section{KESIMPULAN}

Berdasarkan pembahasan penelitian dapat disimpulkan :

a. Hasil penjumlahan dari perkalian setiap bobot alternatif dengan bobot kriteria yang bersesuaian. skor paling tinggi adalah Angga dengan nilai 0,4470 $(0,45)$ dan Arnol dengan nilai $0,3262(0,33)$. Diperoleh hasil akhir bahwa Angga memiliki skor paling tinggi, kemudian Iqbal, Arnol, dan Dwiko. Sehingga karyawan yang pantas mendapatkan lembur adalah Angga.

b. Metode AHP dapat memecahkan permasalahan yang kompleks melalui pendekatan sistem dan pengintegrasian secara deduktif sehingga menentukan karyawan lembur dapat terlaksana dengan objektif.

\section{DAFTAR PUSTAKA}

Abdul Mutholib, Silvia Febrina. 2017. Penerapan Metode Analytical Hierarchy Process (AHP) Pada Aplikasi Pendukung Keputusan Seleksi Karyawan Unicharm Indonesia, Jurnal Sistem Informasi. Teknologi Informatika dan Komputer.

Aji Sasongko, Indah Fitri Astuti, Septya Maharani. 2017. Pemilihan Karyawan Baru Dengan Metode AHP (Analytic Hierarchy Process). Jurnal Informatika Mulawarman.

Bayu Hartono, Muh. Hasbi, Tri Irawati,2014. Sistem Informasi Penggajian Pegawai Secara Multiuser Pada Stikes Duta Gama Klaten. Jurnal Ilmiah SINUS.

Ebedia Hilda Am, Erna Kumalasari N., Rr. Yuliana Rachmawati K. 2015. Penerapan Metode Analytical Hierarchy Process (AHP) Pada Sistem Pendukung Keputusan Pemilihan Mahasiswa Berprestasi Menggunakan Framework Laravel. Jurnal SCRI.

Faisal, 2015. Sistem Pendukung Keputusan Pemilihan Perangkat Lunak Layanan Pengolah

Pemungutan Suara Elektronik Dalam Mendukung Pemberdayaan Peningkatan Kualitas Pendidikan. Jurnal Teknologi Informasi.

Frieyadie. 2017. Penerapan Metode AHP Sebagai Pendukung Keputusan Penetapan Beasiswa. Jurnal Pilar Nusa Mandiri. 
Jurnal Inkofar * Volume 1 No. 2, Desember 2018 * ISSN: 2615-3645 (Print) / 2581-2920 (Online)

Tersedia secara online di: http://www.politeknikmeta.ac.id/meta/ojs/

Sari. 2017. Perancangan Aplikasi Sistem Pakar Dengan Menggunakan Metode Certainty Factor Untuk Menentukan Jenis Gangguan Disleksia Berbasis Web. Jurnal Infokar. Politeknik Meta Industri.

Sean A. M. Pebakirang, Agung Sutrisno, Johan Neyland. 2016. Penerapan Metode AHP (Analytical Hierarchy Process) untuk Pemilihan Supplier Suku Cadang di PLTD Bitung. Jurnal Online Poros Teknik Mesin.

Thomson Mary. 2016. Yusran. Sistem Pendukung Keputusan Menggunakan Metode Analytic Hierarchy Process (AHP) Pemilihan Metode Pembelajaran untuk Mata Kuliah Praktikum yang Berbasiskan Bahasa Pemrograman Komputer. Jurnal Edik Informatika, Penelitian Bidang Komputer Sains dan Pendidikan Informatika. 